\title{
Viewpoint: Western juniper expansion: Is it a threat to arid northwestern ecosystems?
}

\author{
A. JOY BELSKY
}

The author is staff ecologist, Oregon Natural Resources Council, 5825 N. Greeley; Portland, Ore. 97217.

\begin{abstract}
Many ranchers, rangeland managers, and range scientists in the Pacific Northwest consider western juniper (Juniperus occidentalis Hook.) to be an invading weed that reduces water infiltration, dries up springs and streams, increases erosion, reduces biodiversity, and reduces the quality and quantity of forage for livestock and wildlife species. Although there is little scientific evidence supporting most of these beliefs, they are currently being used as rationales for controlling juniper on public and private lands. Similar views were held about pinyon-juniper woodlands in the Southwest and Great Basin from the 1940's through the 1960's, when efforts were also made to control woodland expansion.

Pressures to control the further spread of western juniper and reduce its density in woodlands are increasing. Because of the paucity of information on the environmental effects of western juniper expansion in the Northwest, this paper primarily reviews evidence from earlier studies of pinyon-juniper woodlands in the Southwest and Great Basin. These studies rejected similar assumptions about the deleterious effects of pinyon-juniper expansion on ecosystem properties and call into question current rationales for controlling western juniper in the Northwest. These studies also suggest that while the expansion of juniper might alter species composition and decrease herbaceous biomass in grasslands and shrublands, they have few detrimental effects on streamflow, aquatic organisms, soil properties, or wildlife habitat.
\end{abstract}

Key Words: Western juniper expansion, juniper control, Juniperus occidentalis, pinyon-juniper woodlands, wildlife habitat

Over the past 100 years, western juniper (Juniperus occidentalis Hook:) woodlands, which represent the northwestern extension of the pinyon-juniper woodlands of the Great Basin (Young and Evans 1981), have greatly expanded their range. Whereas these woodlands were once confined to rocky ridges and unproductive areas (Eddleman and Miller 1992), they have recently spread to

The author thanks W.P. Clary, M. Liverman, M.P. McClaran, P.M. Miller, R.F. Miller, J. Skovlin, and A.R. Tiedemann for their thoughtful comments on earlier drafts of this paper, and The Homeland Foundation for generously supporting this work.

Manuscript accepted 24 Aug. 1995. more productive sites and now occupy over one million hectares of eastern Oregon, southwestern Idaho, and northeastern California (Miller and Wigand 1994). Similar to earlier expansions of pinyon-juniper communities in the Southwest and Great Basin, this expansion is most likely due to livestock grazing and reductions in fire frequency (Ellison 1960, Burkhardt and Tisdale 1978, Young and Evans 1981, Eddleman 1987, Neilson 1987. Evans 1988, Miller and Wigand 1994). The close temporal association between juniper expansion and the introduction of large numbers of livestock into the region (both beginning in the late 1800 's) lends strong support to the conclusion that livestock grazing and the concomitant reduction in fire frequency (due to loss of fine fuels from grazing) are the major causes of the expansion.

Climate change and increases in atmospheric carbon dioxide $\left(\mathrm{CO}_{2}\right)$ have also been suggested as contributing to juniper spread: juniper numbers are known to fluctuate with changes in precipitation, and $\mathrm{CO}_{2}$ concentrations have been increasing over the last 200 years (Miller and Wigand 1994, Miller et al. 1994). So far, however, there is little evidence to suggest that these factors are important causes of juniper expansion (Archer 1994). The climate change hypothesis can be challenged because, prior to the current expansion, western juniper expanded only during wet periods (Wigand 1987); currently, we are in a dry period (Miller and Wigand 1994). Although Miller and Wigand (1994) argue that the relatively wet period from 1850 to 1916 stimulated the recent expansion, short moist periods have occurred regularly in the past (Antevs 1938) without a corresponding response from juniper (Miller and Wigand 1994, Fig. 7). The exponential population growth of western juniper during the severe droughts of the last sixty years (Miller et al. 1994) also lends little support to the hypothesis that the current juniper expansion is in response to moist climatic conditions.

The hypothesis that increasing concentrations of atmospheric $\mathrm{CO}_{2}$ have contributed to juniper expansion is intriguing, since $\mathrm{CO}_{2}$ levels have increased $30 \%$ since the Industrial Revolution. Archer (1994) argues against this hypothesis because the increase was only $11 \%$ at the time of the initial buildup of juniper in the late $1800 \mathrm{~s}$ and because few of the vegetational changes predicted to accompany higher $\mathrm{CO}_{2}$ levels have taken place. This absence of predicted effects on vegetation is due, in part, to plant growth in natural communities being constrained by a large number of biotic and abiotic factors besides $\mathrm{CO}_{2}$. Polley et al. (1994), for example, found that although monocultures of honey mesquite (Prosopis glandulosa Torr. var glandulosa), a woody species cur- 
rently expanding its range in the Southwest, responded to higher $\mathrm{CO}_{2}$ levels with increased water use efficiency and belowground biomass, it showed no response when grown in mixture with a grass. They concluded that "much of the potential [increased growth] response of $P$. glandulosa to $\mathrm{CO}_{2}$ concentrations . . . appears to be contingent on the shrub escaping competition (p. 976)". Similar research has not been conducted on western juniper, but it is likely that positive responses to $\mathrm{CO}_{2}$ will also depend an reduction in interspecific competition. Since competing grasses also benefit from higher $\mathrm{CO}_{2}$ concentrations (Smith et al. 1987), the actual effects of $\mathrm{CO}_{2}$ enrichment on the structure of northwestern rangelands are unknown.

Whatever the causes, western juniper woodlands in the Northwest are currently expanding at an unprecedented rate, and herbaceous production has seriously declined (Bedell et al. 1993, Miller and Wigand 1994). Land management agencies and private land owners are under increasing pressure to combat this expansion and are initiating juniper-control measures throughout the region.

\section{The Rationale for Juniper Control}

Whereas improvement of forage for livestock is the major reason given for juniper control on private lands (Bedell 1987a), the emphasis for control on public lands has shifted from forage production to improving ecosystem characteristics. In one recently proposed plan to remove juniper from selected areas in southcentral Oregon, the Bureau of Land Management (BLM) (1993) discussed improved capture and storage of water in soils, improved late-season streamflow, reduced erosion, improved forage and thermal cover for big-horned sheep (Ovis canadensis), increased open country for nesting of loggerhead shrikes (Lanius ludovicianus), and improved fish habital with more harvestable fish. Similarly, a 1994 Environmental Assessment Register for BLM land in southeastern Oregon (BLM 1994) recommended juniper control to improve "riparian habitat and increase streamflow for red band trout (Onchorhynchus mykiss)".

These management decisions are based upon the perception, common throughout the Northwest, that junipers are weedy nuisances that are invading and degrading large areas of otherwise productive rangelands (Elbert 1994, Swan 1994). A typical statement found in an Oregon State University Extension Service publication is: "If not managed, western juniper comes to dominate a majority of eastern Oregon range sites" (Bedell, et al. 1993, p. 3). (This assertion, however, is contradicted by US Forest Service, BLM, and US Fish and Wildlife surveys showing that approximately $5 \%$ of eastern Oregon is currently or will potentially be affected by juniper encroachment (Oregon Department of Fish and Wildlife 1993).) Bedell et al. (1993) also state that such occupancy by juniper is expected to result in "massive watershed degradation, which seriously affects productivity, biodiversity, water quantity and quality, and resource values with drastic economic and ecological consequences". Similarly, Rumpel, et al. (1991) of the BLM Western Juniper Working Group stated that the "areas of [juniper] encroachment are quite capable of setting into motion most of the known processes of desertification within the next 50-75 years over a very large portion of eastern Oregon".

In these and other publications, letters, and newspaper articles, western junipers are blamed for changing western ecosystems by
(1) causing springs and small streams to dry up; (2) endangering fish and aquatic life; (3) increasing overland water flow and soil erosion; (4) reducing the diversity of plants and wildlife; and (5) reducing forage production for livestock and wildlife (Eddleman 1987, Bedell 1987b, Bedell et al. 1993, Miller et al. 1987).

Scientific evidence for most of these beliefs, however, is lacking. There have been no longitudinal studies measuring changes in ecosystem properties during succession from grasslands to western juniper woodlands and only a handful of studies on the effects of juniper removal. In spite of this, there are strong pressures to control western juniper throughout its range. Interestingly, the reasons given for the necessity to control juniper are exactly the same as those given $30-50$ years earlier for controlling the expansion of pinyon and juniper species in the Southwest and Great Basin. Research at that time provided managers with data for testing the validity of their assumptions.

Before large-scale western juniper control begins, it is important to review the reasons given for juniper control and test them against all available information. Besides using the limited data from the Northwest, I'll refer to the more extensive research from pinyon-juniper woodlands in the Southwest and Great Basin. There are, of course, differences among regions in terms of climate, soils, and species, but juniper and pinyon-juniper woodlands are part of the same community-type (West 1984) and are similar enough for the earlier studies on pinyon-juniper woodlands to provide insights into the possible responses of northwestern ecosystems to control programs.

\section{Pinyon-Juniper Control: A Historic Perspective}

Post-settlement expansion of pinyon-juniper woodlands in the Southwest and Great Basin has also long concerned land managers. From the 1940's through the 1960's, hundreds of thousands of hectares of public and private woodlands were cabled, chained, bulldozed, and treated with herbicide to convert them to grasslands (West 1984, Ripple et al. 1983, Dalen and Snyder 1987, Johnsen 1987).

It was generally agreed that these control measures were largely designed to benefit the livestock industry; removal of competitively dominant trees released nutrient and water resources to the less competitive herbaceous species (West 1984, Dalen and Snyder 1987). But the possibility of increasing water yields to streams in arid environments, improving wildlife habitat, and providing a source of wood-fiber for local communities also had great appeal. Due to high costs of woodland conversion, however, most control efforts proved uneconomical. Concerns about the effects of pinyon and juniper control on wildlife habitat and rapid re-invasion of trees after conversion led to doubts about the policy, as did studies showing that the additional benefits of increased water yield and reduced erosion did not materialize. As a result, woodland conversion in pinyon-juniper dominated areas of the West was reduced and in some areas completely abandoned (Clary et al. 1974, West 1984, Dalen and Snyder 1987).

\section{Is Western Juniper a "Weed" that Invades and Infests Western Rangelands?}

Although it is true that pinyon-juniper and western juniper are rapidly expanding their ranges throughout the west, they have 
long been important constituents of regional landscapes (Betancourt 1987, Davis 1987, West and Van Pelt 1987, Miller and Wigand 1994). Prior to the introduction of livestock into the Northwest in the late 1800 s, western juniper was confined by recurrent fires and competitive interactions with herbaceous species to rock outcrops, shallow soils on fractured bedrock, and deep pumice soils (Dealy et al. 1978, Martin 1978, Bedell et al. 1993). Over the last century, juniper has spread to more productive sites. Once established, juniper density has increased and grassland communities have developed into late-successional woodlands (West and Van Pelt 1987, Evans 1988). At current levels of livestock grazing and fire control, western-juniper woodland represents the final phase of vegetational succession in parts of Oregon, California, and Idaho. It's success is partially attributable to its being well adapted to many northwestern soils and climates (e.g. Bedell 1987b, Leonard et al. 1987, Mehringer and Wigand 1987).

Analyses of fossil pollen extracted from lake beds, and seeds, stems, and leaves found in ancient woodrat middens have revealed that the recent expansion of western juniper woodlands in the Intermountain West is not unique (other than its expansion during a period of increasing aridity) (Neilson 1987, Wigand 1987, Miller and Wigand 1994). Fossil evidence suggests that western juniper occurred near Lava Beds National Monument in northeastern California at least 5,300 years Before Present (B.P.) and in Diamond Craters in eastern Oregon at least 4800 B.P. Mehringer and Wigand (1987) suspect that western juniper may have occupied rocky sites in much of its current range 6000 years ago. During the period of 4000-2000 B.P., the range of western juniper expanded and contracted several times in response to increasingly mesic or xeric conditions, respectively, and occurred over areas often greater than those of today. The current rangeexpansion of juniper over the last 100-150 years may be no more extensive than similar expansions 1600 years ago, 850 years ago, and 200-400 years ago (Mehringer and Wigand 1987, Wigand 1987).

Western juniper, therefore, should not be referred to as an invasive weed that is threatening natural communities, but as a native species that becomes a community dominant under certain environmental conditions. It is an important western tree species, whose range fluctuates locally in response to fire. The current expansion differs significantly from prior expansions in that this time, western juniper is spreading under increasingly xeric conditions and its densities are higher (Miller and Wigand 1994).

\section{Do Western Junipers Dry up Springs and Reduce Water Quantity in Rivers?}

Although many ranchers and range managers believe that junipers dry up springs and reduce streamflow and that water suddenly reappears when the trees are removed (Eddleman and Miller 1992, Bedell et al. 1993, Swan 1994), there is little substantive evidence to support these beliefs. I could only find anecdotal accounts of increased spring or streamflow after juniper removal. Hibbert (1933), Brown (1987a), and Schmidt (1987) found little evidence to support similar views about pinyonjuniper expansion; most experimental studies showed that pinyon-juniper removal did not increase water yield. One study that did show increased yield was by Clary et al. (1974), who con- ducted a paired watershed study in which pinyon-juniper woodlands in Arizona were removed by herbicide, chaining, or cutting. They found no changes in streamflow in watersheds where the trees were removed by cabling and then burned or were felled by hand and left in place; however, streamflow increased in watersheds where trees were killed by herbicide and left standing. The increased water yield in this one treatment may be due to the absence of soil disturbance and continued shade from the standing dead trees.

The effects of woodland removal on water yield will, of course, vary with amount and distribution of precipitation, mean temperature, geologic substrate, and soil depth; blanket predictions on water yield, therefore, should not be made. One must also be cautious about extrapolating conclusions from studies performed in the Southwest, where precipitation occurs predominantly in summer months, to the Northwest, where precipitation is predominantly in the winter and temperatures are lower. However, similarities in vegetational structure, ecosystem properties, and histories of the 2 areas suggest that these earlier studies should not be ignored.

The belief that trees reduce streamflow may have arisen from the fact that trees intercept a significant fraction of annual snow and rainfall, reducing the amount of precipitation reaching the ground. Trees also take up large volumes of water through their roots and lose it through transpiration (Eddleman and Miller 1992). Since it appears obvious that more water would be lost from large trees than small grasses and shrubs per unit area of ground, it seems intuitively clear that more water would reach and remain in the ground if trees were removed. Adding to the perception that junipers are "water sucking weeds" (Swan 1994) is the often quoted report that a single juniper ( $>45 \mathrm{~cm}$ in $\mathrm{dbh})$ can lose 120-160 liters of water per day (Bedell et al. 1993), a figure repeated often in the popular press (e.g. Kepple 1993, Maben 1993, Elbert 1994).

These popular conclusions about junipers ignore many of the complexities of natural ecosystems, including the following:

1. In arid and semi-arid climates, most snow- and rain-water simply recharges the soil column; little excess is available to move downslope to streams (Hibbert 1983, West 1984),

2. Herbaceous plants and shrubs that replace trees also intercept rain and snow, reducing the amount of water reaching the ground;

3. Replacement plants also transpire and deplete soil water (Clary et al. 1974, Brown 1987a);

4. Tree removal exposes the soil and understory plants to direct sunlight, causing elevated temperatures and increased evapotranspiration (Clary et al. 1974, Everett and Sharrow 1985);

5. Tree removal exposes soils and understory plants to more wind, which increases evapotranspiration (Everett and Sharrow 1985); and

6. In areas where water is in excess of that needed to recharge the soil, this water may go to shallow aquifers rather than to streams (Hibbert 1983).

In other words, studies showing that junipers intercept precipitation and transpire water (Young and Evans 1987, Eddleman and Miller 1992) cannot be used to conclude that this lost water would have ended up in streams and springs. To do so, water budgets of juniper-dominated and juniper-free sites would have to be compared, or long-term changes in streamflow following juniper removal measured. Currently, available evidence suggests 
that there will be few effects, or that these effects will occur only in selected watersheds or parts of watersheds.

Without increases in streamflow or reduced sediment discharge into streams (see below), water quantity and quality following juniper removal would remain unchanged. There is, therefore, no reason to believe that fish habitat would be improved or recreational fishing would increase following juniper control.

\section{Does Juniper Reduce Water Infiltration into Soils and Increase Erosion?}

Because juniper out-competes herbs and shrubs for light and belowground resources (Vaitkus and Eddleman 1987, McPherson and Wright 1990), more bare ground is usually exposed in juniper woodlands than in grasslands. It has been suggested that by reducing ground-cover, junipers also reduce water infiltration into the soil, thereby increasing overland flow and surface erosion. One study did find lower infiltration and higher erosion rates in western juniper woodlands than in other northwestern range and forest communities (Buckhouse and Mattison 1980), but another study did not (Gaither and Buckhouse 1983). Additional work on pinyon-juniper woodlands in the Southwest and Great Basin also failed to find lower water infiltration rates or more erosion than in other communities (Gifford et al. 1970, Gifford 1973, Clary et al. 1974, Renard 1987, Schmidt 1987), and Evans (1988) concluded that most storms in these woodlands caused little or no runoff. Consequently, there would be no additional discharge of sediments into streams or reduction of water quality. Although the effects of woodlands on infiltration and erosion are most probably site-specific (Blackburn and Skau 1974), varying with soil type, slope, disturbance, vegetation cover, and frost dynamics (Wilcox 1994), most of the available evidence suggests that western juniper has few, if any, negative effects on water infiltration or soil erosion.

The often neutral effects of juniper woodlands on these soil properties are not well understood; but they may be related to the physical presence of trees. Heavy rainfall on bare ground dislodges soil particles and is a major cause of erosion. However, when the ground is covered by tree crowns, the energy of falling raindrops is absorbed by tree leaves and stems and less soil is disturbed. Additionally, the buildup of a thick duff layer below tree crowns may impede downhill flow and increase water infiltration (Renard 1987). If so, erosion would gradually decrease during stand development and crown closure.

Juniper may also have fewer effects on water infiltration and erosion than livestock, which reduce vegetative cover and disturb soils with their hooves (Wilcox 1994). Evans (1988), in fact, blamed excessive rates of runoff and sediment production in pinyon-juniper woodlands on overgrazing and other human uses, since herbaceous cover is significantly lower in grazed than ungrazed woodlands (McPherson and Wright 1990). In some cases, trees may even protect the soil since livestock numbers may be lower and disturbance less extensive in woodlands, where forage is less abundant, than in open grasslands (Dadkhah and Gifford 1980). Consequently, Gifford (1987) hypothesized that runoff and erosion should be no greater (and perhaps less) in woodlands than in areas with fewer trees and more grazing animals.

\section{Do Junipers Reduce Grassland Production and Forage Quality?}

Mature pinyon and juniper trees are better competitors for light, water, and nutrients than herbs and shrubs; as tree density increases, herbaceous and shrub biomass declines (Clary and Jameson 1981, Doughty 1987, Pieper 1990, Vaitkus and Eddleman 1987). Conversely, as tree density is reduced through cutting, burning or chaining, additional resources become available to subordinate species and herb and shrub biomass increases (Bedell 1987b, Brown 1987b, Clary 1987, but see Everett and Sharrow 1985). Removal of Utah juniper [Juniperus osteosperma (Torr.) Little] in Arizona, for example, resulted in a $440 \%$ increase of understory biomass (Clary 1971).

Removal of juniper and pinyon-juniper, however, does not always lead to increased production of high quality forage for livestock or wildlife (Evans 1988). Shrubs may respond more quickly than herbaceous species to the removal of trees and release of resources, further reducing grass and forb biomass (Rippel et al. 1983). Work in the Northwest has shown that if perennials are sparse or if annual weeds abundant before treatment, juniper control may open the site to increased dominance by annual grasses and forbs. Evans and Young (1985, 1987), for example, found that a site in California from which western juniper had been cleared was colonized and eventually dominated by low-quality annuals such as cheatgrass (Bromus tectorum L.) and medusahead [Taeniatherum asperum (Sim.) Nevski]. And Vaitkus and Eddleman (1987) found that although herbaceous production doubled after the removal of western juniper in eastern Oregon, much of this increase came from annual forbs such as fireweed (Epilobium paniculatum Nutt.), possibly due to an abundant seed reserve in the soil. They concluded that "an increase in herbage production after tree removal does not necessarily result in an improvement in range condition" (p. 459).

Burning to control juniper has also led to unexpected and undesirable effects. Bunting (1987) found that at fire intensities necessary to kill juniper, there was substantial mortality of native perennial grasses such as Idaho fescue (Festuca idahoensis Elmer) and bluebunch wheatgrass [Pseudoroegneria spicata (Pursh) A. Löve]. This mortality left the site open for colonization by cheatgrass and fireweed. Although Martin (1978) did not find such high mortality in perennial grasses, he did find that fire could lead to increased dominance by cheatgrass. Other studies using fire to control pinyon and juniper (Everett 1987a) suggested that as perennial cover, seed production, and dormant seed reserves in a site decline, annual grasses and forbs become more likely to revegetate the site. Everett (1987a) also found that perennial species established best on moist north- and east-facing slopes while annuals established best on the dry south- and westfacing slopes. He concluded that "postfire grass cover is a function of preburn conditions" (p. 155), suggesting that burning will have highly variable but predictable effects. It is probably safe to conclude that the most favorable response to juniper control, in terms of forage production, would occur in low density woodlands having a full complement and high densities of desirable forage species. These species would then be available to take advantage of the newly released resources for population growth. 


\section{Does Juniper Degrade Wildlife Habitat and Reduce Biodiversity?}

Both pinyon-juniper and western juniper woodlands have high diversities of vertebrate species. Pinyon-juniper woodlands provide seasonal-to-year-long habitat for over 150 vertebrate species (Buckman and Wolters 1987), many of which decline in abundance with reductions in woodland. In Oregon, 95-146 species of wildlife regularly occur in juniper woodlands (Oregon Department of Fish and Wildlife 1993). Gashwiler (1977) found that juniper woodlands in Oregon had larger numbers of bird species throughout the year than big sagebrush (Artemesia tridentata Nutt.), ponderosa pine (Pinus ponderosa Laws.), or lodgepole pine (Pinus contorta Loudon) communities. Maser and Gashwiler (1978) attributed the higher diversity of bird species in juniper woodlands to high structural diversity, large numbers of sites for perching, singing, nesting, and drumming, and plentiful berries and high insect diversity for food. They attributed high mammal diversity in the same communities to the presence of hollow trunks, shade, thermal cover, and foliage and berries for food.

Balda (1987), in a discussion of the diversity of birds in pinyon-juniper woodlands, reported that he knew of "no other plant community in North America in which the dominant plant species have coevolved and [formed] mutualistic relationships with animals." Removal of juniper woodland would, of course, improve habitat for open-grassland- and shrub-steppe-adapted species, but not for those species that utilize trees for perches, food, thermal cover, and nesting cavities. Biodiversity most likely would be optimized by a landscape containing a mosaic of woodlands, grasslands, and intermediate seral communities. Habitat would then be available for plant and animal species associated with all habitat types.

While some wildlife species benefit from a reduction in woodland cover, other species may suffer (Buckman and Wolters 1987. Stevens 1987), as demonstrated by the many pinyonjuniper reduction projects that have resulted in less productive, rather than more productive, wildlife habitat (Stevens 1987). Sedgwick and Ryder (1987) found, for example, that while the chaining of trees from a pinyon-juniper woodland in Colorado increased herbaceous production by more than $700 \%$, it significantly reduced site utilization by birds. As a result, avifauna diversity was higher in woodlands than in chained sites. In contrast, the authors found that small-mammal abundances were higher on the chained site. Howard et al. (1987) found that mule deer showed increased use of cabled areas in the spring and lagomorphs showed increased use of cabled areas in all seasons except winter. Nevertheless, woodland clearance has generally shown few effects on population sizes of big-game species such as deer and elk (Terrell and Spillett 1975, Skousen et al. 1989). As a consequence of these variable responses to pinyon-juniper control, Gifford (1987) concluded that "[b]lanket statements are obviously out of place..." (p. 36).

\section{A few last Thoughts}

I am not advocating a "no control" approach to western juniper expansion in the Northwest. Any vegetation change resulting from human activities is a cause for concern, especially when it is altering over a million hectares of western landscapes. I am simply advocating that land managers recognize the environmentally "noisy" real world, instead of hoping that the removal of juniper will solve their problem of expanding woodlands plus result in numerous environmental benefits. Past research in western juniper woodlands and pinyon-juniper woodlands of the Great Basin and the Southwest strongly suggests that these solutions and benefits will not materialize.

Factors determining the responses of arid and semi-arid communities to pinyon and juniper removals are complex and sitespecific, and "common knowledge" is often wrong. Before the effects of juniper clearance in the Northwest can be predicted, longitudinal and/or comparative studies are required in a wide range of sites and in stands of different ages and densities. In spite of the conviction that junipers are degrading western rangelands and wildlife habitat, there is little or no experimental evidence suggesting that this is so or that juniper control will (1) increase water yield to springs and streams, (2) increase water infiltration, (3) reduce erosion, or (4) improve fish and wildlife habitat. It is probably safe to predict that tree removal will increase the productivity of understory shrubs and herbaceous plants, including, in some cases, the productivity of undesirable weedy annuals and shrubs. The trade-offs need to be recognized and analyzed.

Most of the earlier studies of juniper and pinyon-juniper removal were carried out on sites that were grazed by domestic livestock. The effects of livestock grazing and tree removal were therefore confounded, making it difficult to determine whether the resulting changes in biotic communities and ecosystem function were due to reduced tree densities, changes in livestock abundance and utilization patterns, or their interactions. It is also unknown to what degree herbaceous production would have differed if livestock grazing had been deferred, reduced, or eliminated. Without studies in which these two variables are controlled and investigated individually, it is impossible to ascertain the true impacts of western juniper on northwestern range ecosystems.

As the demands for forage and wood fiber increase, the pressure for juniper clearance will also increase (Tidwell 1987). The combined effects of logging and livestock grazing on ecosystem nitrogen stores may substantially degrade these ecosystems (Klopatek 1987, Tiedemann 1987), since most of the nitrogen in junipers is in aboveground tissues. Loss of this nitrogen to logging or fire could substantially deplete the ecosystem's nitrogen reserves and reduce its future productivity. Even the removal of tree boles for commercial uses may result in significant losses of nitrogen. Planning for large-scale logging of northwestern juniper woodlands for wood products is currently underway (Swan 1994). In regions where the soil nitrogen levels are low and plants nitrogen limited, such activities might not only be unsustainable, but they might significantly alter and degrade whole ecosystems. Before large-scale juniper clearance or logging programs are initiated, managers must understand and carefully evaluate the consequences of their actions. One thing is clear: responses of arid northwestern communities to juniper control will be site specific. Currently, so little is known about the effects of juniper control or large-scale juniper logging on environmental attributes that it is difficult to predict whether a given site will respond to tree removal by increased growth of desirable bunchgrasses, higher density of introduced weeds, reinvasion of juniper, or significantly reduced productivity. Studies reviewed in 
this paper call into question whether any of the widely predicted benefits of juniper control will actually occur.

Gifford (1987) commented at the Pinyon-Juniper Conference (Everett 1987b) on what he calls the myths and fables that have grown up around the pinyon-juniper community-type. It shows his concern about allowing these myths and misconceptions to continue to guide management decisions and about the need to monitor treated lands and evaluate these decisions.

"It seems reasonable to suggest that before large sums of money are expended to modify a plant community, that baseline data be gathered to reflect existing conditions ... and then, if change is initiated, that data be collected to substantiate whether or not any of the initial objectives were met. If baseline and post-treatment evaluation monies are not available, then the project should never be approved. This equates to professional accountability."

\section{Literature Cited}

Antevs, E. 1938. Rainfall and tree growth in the Great Basin. Carnegie Institute of Washington, Pub. 469, Amer. Geogr. Soc., Spec. Pub. 21.

Archer, S. 1994. Woody plant encroachment into southwestern grasslands and savannas: rates, patterns and proximate causes. p. 13-68. In: Vavra, M., W.A. Laycock, and R.D. Pieper, (eds.). Ecological implications of livestock herbivory in the west. Soc. for Range Manage., 1839 York Street, Denver, Colo.

Balda, R.P. 1987. Avian impacts on pinyon-juniper woodlands, p. 525-533. In: Everett, R.L., (ed.). Proc.-Pinyon-juniper conference. USDA. Forest Serv. Gen. Tech. Rep. INT-215.

Bedell, T.E. 1987a. Rehabilitation of western juniper rangeland: a case history. p. 313-315. In: Everett, R.L., (ed.). Proc.-Pinyon-juniper conference. USDA Forest Serv. Gen. Tech. Rep. INT-215. Corvallis, Ore.

Bedell, T.E. 1987b. Range management concerns on juniper woodlands. p. 436-429. In: Everett, R.L., (ed.). Proc.-Pinyon-juniper conference. USDA Forest Serv. Gen. Tech. Rep. INT-215.

Bedell, T.E., L.E. Eddleman, T. Deboodt, and C. Jacks. 1993. Western juniper-its impact and management in Oregon rangelands. Oregon State Univ. Ext. Serv.

Betancourt, J.L. 1987. Paleoecology of pinyon-juniper woodlands: summary. p. 129-139. In: Everett, R.L., (ed.). Proc.-Pinyon-juniper conference. USDA Forest Serv. Gen. Tech. Rep. INT-215.

Blackburn, W.H., and C.M. Skau. 1974. Infiltration rates and sediment production of selected plant communities in Nevada. J. Range Manage. 27:476-480.

Brown, T.C. 1987a. The value of incremental water flow from pinyonjuniper lands. p. 177-182. In: Everett, R.L., (ed.). Proc.-Pinyonjuniper conference. USDA Forest Serv. Gen. Tech. Rep. INT-215.

Brown, R.W. 1987b. Ecophysiology and water relations research in the pinyon-juniper vegetation type. p. 398-405. In: Everett, R.L., (ed.). Proc.-Pinyon-juniper conference. USDA Forest Serv. Gen. Tech. Rep. INT-215.

Buckhouse, J.C., and J.L. Mattison. 1980. Potential soil erosion of selected habitat types in the high desert region of central Oregon. J. Range Manage. 33:282-285.

Buckman, R.E., and G.L. Wolters. 1987. Multi-resource management of pinyon-juniper woodlands. p. 2-4. In: Everett, R.L., (ed.). Proc.Pinyon-juniper conference. USDA Forest Serv. Gen. Tech. Rep. INT215.

Bunting, S.C. 1987. Use of prescribed burning in juniper and pinyonjuniper woodlands. p. 141-144. In: Everett, R.L., (ed.). Proc.Pinyon-juniper conference. USDA Forest Serv. Gen. Tech. Rep. INT215.

Bureau of Land Management. 1993. Warner Lakes Proposed Plan Amendment for juniper management on selected areas of the Lakeview Resource Area, Oregon. E.A. Number OR-010-02-19.
Bureau of Land Management. 1994. Burns District Planning Update. BLM/OR/WA/PL-94/8-1792.

Burkhardt, J.W. and E.W. Tisdale. 1976. Causes of juniper invasion in southwestern Idaho. Ecol. 57:472-484.

Clary, W.P. 1971. Effects of Utah juniper removal on herbage yields from Springerville Soils. J. Range Manage. 24:373-378.

Clary, W.P. 1987. Herbage production and livestock grazing on pinyonjuniper woodlands. p. 440-447. In: Everett, R.L., (ed.). Proc.Pinyon-juniper conference. USDA Forest Serv. Gen. Tech. Rep. INT215.

Clary, W.P., and D.A. Jameson. 1981. Herbage production following tree and shrub removal in the pinyon-juniper type of Arizona. J. Range Manage. 34:109-113.

Clary, W.P., M.B. Baker, Jr., P.F. O'Connell, T.N. Johnson, Jr., and R.E. Campbell. 1974. Effects of pinyon-juniper removal on natural resource products and uses in Arizona. USDA Forest Serv. Res. Paper RM-128.

Dadkhah, M., and G.F. Gifford. 1980. Influence of vegetation, rock cover, and trampling on infiltration rates and sediment production. Water Resour. Bull. 16:979-986.

Dalen, R.S., and W.R. Snyder. 1987. Economic and social aspects of pinyon-juniper treatment-then and now. p. 343-350. In: Everett, R.L., (ed.). Proc.--Pinyon-juniper conference. USDA Forest Serv. Gen. Tech. Rep. INT-215.

Davis, O.K. 1987. Palynological evidence for historic juniper invasion in central Arizona: a late-Quaternary perspective. p. 120-124. In: Everett, R.L., (ed.). Proc-_-Pinyon-juniper conference. USDA Forest Serv. Gen. Tech. Rep. INT-215.

Dealy, J.E., J.M. Geist, and R.S. Driscoll. 1978. Western juniper communities on the rangelands of the Intermountain Northwest. p. 11-29. In: Proc. Western juniper ecology and management workshop. Bend, Ore. USDA Forest Serv. Gen. Tech. Rep. PNW-74.

Doughty, J.W. 1987. The problems with custodial management of pinyon-juniper woodlands. p. 29-33. In: Everett, R.L., (ed.). Proc.Pinyon-juniper conference. USDA Forest Serv. Gen. Tech. Rep. INT215.

Eddleman, L.E. 1987. Western juniper in central Oregon. p. 255-259. In: Everett, R.L., (ed.). Proc.-Pinyon-juniper conference. USDA Forest Serv. Gen. Tech. Rep. INT-215.

Eddleman, L.E., and P.M. Miller. 1992. Potential impacts of western juniper on the hydrologic cycle. p. 176-180. In: Proc.-Symposium on ecology and management of riparian shrub communities. USDA Forest Serv. Gen. Tech. Rep. INT-289.

Elbert, J. 1994. Too much of a good thing. Herald and News, Klamath Falls, Ore. (24 April 1994).

Ellison, L. 1960. Influence of grazing on plant succession of rangelands. Bot. Rev. 26:1-78.

Evans, R.A. 1988. Management of pinyon-juniper woodlands. USDA Forest Serv. Gen. Tech. Rep. INT-249.

Evans, R.A., and J.A. Young. 1985. Plant succession following control of western juniper (Juniperus occidentalis) with Picloram. Weed Sci. 33:63-68.

Evans, R.A., and J.A. Young. 1987. Control, plant succession, and revegetation in western juniper woodlands. p. 301-304. In: Everett, R.L., (ed.). Proc.-Pinyon-juniper conference. USDA Forest Serv. Gen. Tech. Rep. INT-215.

Everett, R.L. 1987a. Plant response to fire in the pinyon-juniper zone. p. 152-157. In: Everett, R.L., (ed.). Proc.-Pinyon-juniper conference. USDA Forest Serv. Gen. Tech. Rep. INT-215.

Everett, R.L. (ed.) 1987b. Proceedings--Pinyon-juniper conference. USDA Forest Serv. Gen. Tech. Rep. INT-215.

Everett, R.L., and S.H. Sharrow. 1985. Soil water and temperature in harvested and nonharvested pinyon-juniper stands. USDA Forest Serv. Res. Pap. INT-342.

Gaither, R.E., and J.C. Buckhouse. 1983. Infiltration rates of various vegetative communities within the Blue Mountains of Oregon. J. of Range. Manage. 36:58-60.

Gashwiler, J.S. 1977. Bird populations in four vegetational types in central Oregon. USDA Forest Serv. Spec. Sci. Rep.-Wildl. No. 205.

Gifford, G.F. 1973. Runoff and sediment yields from runoff plots on chained pinyon-juniper sites in Utah. J. Range Manage. 26:440-443. 
Gifford, G.F. 1987. Myths and fables and the pinyon-juniper type. p. 34-37. In: Everett, R.L., (ed.). Proc.-Pinyon-juniper conference. USDA Forest Serv. Gen. Tech. Rep. INT-215.

Gifford, G.F., G. Williams, and G.B. Coltharp. 1970. Infiltration and erosion studies on pinyon-juniper conversion sites in southern Utah. J. Range Manage. 23:402-406.

Hibbert, A.R. 1983. Water yield improvement potential by vegetation management on western rangelands. Water Resources Bull. 19: $375-381$.

Howard, V.W., K.M. Cheap, R.H. Hier, T.G. Thompson, and J.A. Dimas. 1987. Effects of cabling pinyon-juniper on mule deer and lagomorph use. p. 552-557. In: Everett, R.L., (ed.). Proc.-Pinyon-juniper conference. USDA Forest Serv. Gen. Tech. Rep. INT-215.

Johnsen, T.N., Jr. 1987. Using herbicides for pinyon-juniper control in the Southwest. p. 330-334. In: Everett, R.L., (ed.). Proc.-Pinyonjuniper conference. USDA Forest Serv. Gen. Tech. Rep. INT-215.

Kepple, T. 1993. Juniperus occidentalis, aka: the range invader. Herald and News, Klamath Falls, Ore. (22 June 1993).

Klopatek, J.M. 1987. Nutrient pattems and succession in pinyon-juniper ecosystems of northern Arizona. p. 391-396. In: Everett, R.L., (ed.). Proc.-Pinyon-juniper conference. USDA Forest Serv. Gen. Tech. Rep. INT-215.

Leonard, S.G., R.L. Miles, and H.A. Summerfield. 1987. Soils of the pinyon-juniper woodlands. In: Everett, R.L., (ed.). Proc.-Pinyonjuniper conference. USDA Forest Serv. Gen. Tech. Rep. INT-215.

Maben, S. 1993. Juniper takeover a mixed blessing for desert. Bulletin Bend, Ore, (2 Sept.,1993).

Martin, R.E. 1978. Fire manipulation and effects in western juniper (Juniperus occidentalis Hook.). p. 121-136. In: Proc. Western juniper ecology and management workshop. Bend, OR. USDA Forest Serv. Gen. Tech. Rep. PNW-74.

Maser, C., and J.S. Gashwiler. 1978. Interrelationships of wildlife and western juniper. p. 37-82. In: Proc. Western juniper ecology and management workshop. USDA Forest Ser. Gen. Tech. Rep. PNW-74.

MicPherson, G.R., and H.A. Wright. 1990. Effects of cattle grazing and Juniperus pinchotii canopy cover on herb cover and production in western Texas. Amer. Midl. Nat. 123:144-151.

Mehringer, P.J., Ir., and P.E. Wigand. 1987. Western juniper in the Holocene. p. 109-119. In: Everett, R.L., (ed.). Proc.-Pinyon-juniper conference. USDA Forest Serv. Gen. Tech. Rep. INT-215.

Miller, R.F. and P.E. Wigand. 1994. Holocene changes in scmiarid pinyon-juniper woodlands. Bioscience 44:465-474.

Miller, R.F., R.F. Angell, and L.E. Eddleman. 1987. Water use by western juniper. p. 418-422. In: Everett, R.L., (ed.). Proc.-Pinyonjuniper conference. USDA Forest Serv. Gen. Tech. Rep. INT-215.

Miller, R.F., T.J. Svejcar, and N.E. West. 1994. Implications of livestock grazing in the Intermountain sagebrush region: plant composition. p. 101-146. In: Vavra, M., W.A. Laycock, and R.D. Pieper, (eds.). Ecological implications of livestock herbivory in the west. Soc. for Range Manage., 1839 York Street, Denver, Colo.

Neilson, R.P. 1987. On the interface between current ecological studies and the paleobotany of pinyon-juniper woodlands. p. 93-98. In: Everett, R.L., (ed.). Proc.-Pinyon-juniper conference. USDA Forest Serv. Gen. Tech. Rep. INT-215.

Oregon Department of Fish and Wildlife. 1993. Application of the habitat mitigation policy to juniper woodland management. Habitat Conserv. Div. 30 pp.

Pieper, R.D. 1990. Overstory-understory relations in pinyon-juniper woodlands in New Mexico. J. Range Manage. 43:413-415.

Polley, H.W., H.B. Johnson, and H.S. Mayeux. 1994. Increasing $\mathrm{CO}_{2}$ : comparative responses of the $\mathrm{C}_{4}$ grass Schizachyrium and grassland invader Prosopis. Ecology 75:976-988.

Renard, K.G. 1987. Present and future erosion prediction tools for use in pinyon-juniper communities. p. 505-512. In: Everett, R.L., (ed.). Proc.-Pinyon-juniper conference. USDA Forest Serv. Gen. Tech. Rep. INT-215.

Rippel, P., R.D. Pieper, and G.A. Lymbery. 1983. Vegetational evaluation of pinyon-juniper cabling in south-central New Mexico. J. Range Manage. 36:13-15.
Rumpel, P., V. Prichard, D. Smith, C. Oke, G. Patterson, and L. Sidebotham. 1991. Memorandum from the Bureau of Land Management Western Juniper Working Group to the OR/WA Management Team concerning expansion of western juniper in eastern Oregon, Vale District Office, Vale Ore. (2 June 1991).

Schmidt, L.J. 1987. Present and future themes in pinyon-juniper hydrology. p. 474-489. In: Everett, R.L., (ed.). Proc.-Pinyon-juniper conference. USDA Forest Serv. Gen. Tech. Rep. INT-215.

Sedgwick, J.A., and R.A. Ryder. 1987. Effects of chaining pinyonjuniper on nongame wildlife. p. 541-551. In: Everett, R.L., (ed.). Proc.-Pinyon-juniper conference. USDA Forest Serv. Gen. Tech. Rep. INT-215.

Skousen, J.G., J.N. Davis, and J.D. Brotherson. 1989. Pinyon-juniper chaining and seeding for big game in central Utah. J. Range Manage. 42:98-104.

Smith, S.D., B.R. Strain, and T.D. Sharkey. 1987. Effects of $\mathrm{CO}_{2}$ enrichment on four Great Basin grasses. Funct. Ecol. 1:139-143.

Stevens, R. 1987. Thirty years of pinyon-juniper big game habitat improvement projects: what have we learned? p. 558-571. In: Everett, R.L., (ed.). Proc.-Pinyon-juniper conference. USDA Forest Serv. Gen. Tech. Rep. INT-215.

Swan, L. 1994. Western juniper management and commercialization: an emerging issue for eastside EIS. Winema National Forest, Klamath Falls Ore. (Unpublished document)

Terrell, T.L., and J.J. Spillett. 1975. Pinyon-juniper conversions: its impact on mule deer and other wildlife. p. 105-119. In: The pinyonjuniper ecosystem: a symposium. Utah State Univer., Logan, Ut.

Tidwell, D.P. 1987. Multi-resource management of pinyon-juniper woodlands: times have changed, but do we know it? p. 5-8. In: Everett, R.L., (ed.). Prac.-Pinyon-juniper conference. USDA Forest Serv. Gen. Tech. Rep. INT-215.

Tiedemann, A.R. 1987. Nutrient accumulations in pinyon-juniper ecosystems-managing for future site productivity. p. 352-359. In: Everett, R.L., (ed.). Proc.-Pinyon-juniper conference. USDA Forest Serv. Gen. Tech. Rep. INT-215.

Vaitkus, M.R., and L.E. Eddleman. 1987. Composition and productivity of a western juniper understory and its response to canopy removal. p. 456-460. In: Everett, R.L., (ed.). Proc--Pinyon-juniper conference. USDA Forest Serv. Gen. Tech. Rep. INT-215.

West, N.E. 1984. Successional patterns and productivity potentials of pinyon-juniper ecosystems. p.1301-1332. In: Developing strategies for rangeland management. National Research Council. Boulder, Colo. Westview Press.

West, N.E. and N.S. Van Pelt. 1987. Successional patterns in pinyonjuniper woodlands. p.43-52. In: Everett, R.L., (ed.). Proc.-Pinyonjuniper conference. USDA Forest Serv. Gen. Tech. Rep. INT-215.

Wigand, P.E. 1987. Diamond pond, Hamey County, Oregon: Vegetation history and water table in the eastern Oregon desert. Great Basin Nat. 47:427-458.

Wilcox, B.P. 1994. Runoff and erosion in intercanopy zones of pinyonjuniper woodlands. J. Range. Manage. 47:285-295.

Young, J.A., and R.A. Evans. 1981. Demography and fire history of a western juniper stand. J. Range Manage. 34:501-505.

Young, J.A., and R.A. Evans. 1987. Stem flow on western juniper (Juniperus occidentalis) trees. p. 373-3S1. In: Everet, R.L., (ed.). Proc.-Pinyon-juniper conference. USDA Forest Serv. Gen. Tech. Rep. INT-215. 